Brazilian Journal

of Chemical

\title{
USING A MEDIUM OF FREE AMINO ACIDS TO PRODUCE PENICILLIN G ACYLASE IN FED- BATCH CULTIVATIONS OF Bacillus megaterium ATCC 14945
}

\author{
R. G. Silva, V. R. Souza, E. R. Nucci, L. M. Pinotti, A. J. G. Cruz, \\ R. C. Giordano and R. L.C. Giordano* \\ Departamento de Engenharia Química, Universidade Federal de São Carlos, \\ Phone: +(55) (16) 3351-8707; fax+(55) (16) 3351-8266, Rodovia Washington Luis, km 235, \\ C P. 676, CEP 13565-905, São Carlos - SP, Brasil \\ E-mail: raquel@power.ufscar.br
}

(Received: October 20, 2004 ; Accepted: October 19, 2005)

\begin{abstract}
The production of penicillin G acylase (PGA, an important industrial enzyme) from a wild strain of Bacillus megaterium using a pool of free amino acids as substrate was studied in a bench-scale bioreactor. Experiments carried out in shakers showed that the substitution of casein for free amino acids in the presence of cheese whey was the culture medium that provided the highest productivity. Several cultivations were carried out in a bioreactor operated in either batch or fed-batch mode. Batch runs showed that enzyme production is associated with microorganism growth. The following set of amino acids was preferentially consumed: Ala, Arg, Asp, Gly, Lys, Ser, Thr and Trp. On the other hand, the rates of consumption of His, Ile, Leu, Met, Phe, Pro, Tyr and Val were lower.

Keywords: Penicillin G acylase production; Bacillus megaterium; Amino acids; Fed-batch cultivation.
\end{abstract}

\section{INTRODUCTION}

Enzymes are highly specific and active under mild (typical biological) environmental conditions. They are the ideal catalyst for environment-friendly processes, following the paradigm of the so-called green chemistry. These characteristics explain the increase in their use in industrial processes (Illanes et al., 1994). Penicillin G acylase, PGA (E.C.3.5.1.11), is an enzyme of great importance to the pharmaceutical industry, which is mostly used in the production of 6-aminopenicillanic acid (6-APA) and 7-aminodesacetoxycephalosporanic acid (7-ACA), key components in the production of $\beta$-lactam antibiotics. PGA is the second most commonly used enzyme worldwide, after glucose isomerase.
Industry has been using immobilized PGA from different microorganisms of which $B$. megaterium and $A$. viscosus are the only ones that reportedly secrete the enzyme into the external medium, thus helping in the process of purification and decreasing the cost of the end-product. PGA production is commonly reported in the literature as coming from Escherichia coli, but Proteus rutgeri and Bacillus megaterium are also mentioned (Ospina, 1992).

The industrial production of a large variety of metabolites occurs in batch and fed-batch cultivation (Modak and Lim, 1992). The success of fed-batch bioreactors is mainly due to the more effective process control and the more efficient use of nutrients, which are characteristic of this mode of operation (Whitaker, 1980). Whenever changes in

*To whom correspondence should be addressed 
nutrient concentration affect productivity or even cause a change in metabolic routes of the microorganism, fed-batch processes are usually better than conventional batches. Some advantages are (Yamane and Shimizu, 1984; Schmidell et al., 2001): (1) Minimization of the undesirable effects of cell metabolism control, such as catabolic repression; (2) prevention of inhibition by substrates or precursors; (3) minimization of the formation of toxic products, a particularly critical factor in highcell-density cultivations. The objective in fed-batch cultivations is to control nutrient concentrations in the medium along the bioreactor trajectory.

Nutrient requirements studies are important for optimizing the medium composition (for example, carbon and nitrogen sources), avoiding the addition of unnecessary components that would make downstream processing more complex. Acevedo and Cooney (1973), Illanes et al. (1994) and Gentina et al. (1997) presented studies on optimization of the culture medium for the production of PGA by $B$. megaterium. Pinotti et al. (2000) confirmed the glucose repression of PGA production by $B$. megaterium and that the presence of cheese whey was necessary for this purpose - probably due to micronutrients in the whey, since lactose consumption was negligible. Therefore, a medium with free amino acids, acting as both nitrogen and carbon sources, was a natural choice at this point, and Souza et al. (2002) studied the effect of the concentration of different free amino acids on the production of the enzyme in shaking flasks.

PGA production experiments were carried out in a bench-scale 5-L bioreactor operated in batch and fed-batch modes, using free amino acids and phenyl acetic acid for both carbon and nitrogen sources. Previous studies carried out in the shaker showed that replacement of casein by free amino acids in the presence of cheese whey provided higher productivity. Batch and fed-batch runs were planned to verify whether enzyme production were strictly associated with microorganism growth and amino acids consumption for this specific medium and whether a preferential consumption of some of the amino acids took place.

\section{MATERIALS AND METHODS}

\section{Materials}

Amino acids (Synth and Sigma), cheese whey (Sigma), phenyl acetic acid (Carlo Erba), mineral salts (Synth-Mallinckrodt) and penicillin G (Paraquímica do Brasil) were used in this work. Other reactants were of analytic grade and were obtained from different suppliers.

\section{Microorganism}

The strain Bacillus megaterium ATCC 14945 was from Fundação Tropical (Campinas, SP, Brazil). It was kept in cryogenic vials at $-60{ }^{\circ} \mathrm{C}$.

\section{Preparation of the Inoculum}

The inoculum was prepared in Erlenmeyer flasks using the medium described in Table 1 . After adding the microorganism, the liquid germination medium was incubated during $24 \mathrm{~h}$ at $300 \mathrm{rpm}$ (in a rotary shaker) and $30^{\circ} \mathrm{C}$. Each nutrient was prepared at a higher concentration, and the amount required to completely fill the flasks was added. The germination medium represented $10 \%$ of the total volume of the reactor used for enzyme production.

Table 1: Composition of the germination medium.

\begin{tabular}{|l|c|}
\hline \multicolumn{1}{|c|}{ Nutrients } & Concentration (g/L) \\
\hline Solution of amino acids & 10.0 \\
Cheese whey & 7.0 \\
Solution of salts & \\
\hline
\end{tabular}

${ }^{1}$ Mixture of amino acids, $40 \mathrm{~g} / \mathrm{L}$ : alanine (Ala) $=1.04$; arginine $(\mathrm{Arg})=1.48$; aspartic acid $($ Asp $)=2.28$; cystine $(\mathrm{Cys})=0.12$; glutamic acid $(\mathrm{Glu})$ = 8.04; glycine $(\mathrm{Gly})=0.4$; histidine.HCl $(\mathrm{His})=0.88$; isoleucine $(\mathrm{Ile})=1.92$; leucine $(\mathrm{Leu})=3.76$; lisine.HCl $(\mathrm{Lys})=2.72$; DL-methionine $(\mathrm{Met})=2.24$; phenylalanine $(\mathrm{Phe})=2.2$; proline $(\mathrm{Pro})=3.88$; serine $(\mathrm{Ser})=2.24$; threonine $(\mathrm{Thr})=1.72$; tyrosine $(\mathrm{Tyr})=1.76$; tryptophane $(\mathrm{Trp})$ $=0.48$; valine $(\mathrm{Val})=2.48$.

${ }^{2}$ Concentrations in mg/L: $\mathrm{MgCl}_{2} .6 \mathrm{H}_{2} \mathrm{O}=338.9 ; \mathrm{CaCl}_{2} \cdot 6 \mathrm{H}_{2} \mathrm{O}=247.9 ; \mathrm{Na}_{2} \mathrm{SO}_{4}=239.9 ; \mathrm{FeCl}_{3} .6 \mathrm{H}_{2} \mathrm{O}=65.3 ; \mathrm{CoCl}_{2} .6 \mathrm{H}_{2} \mathrm{O}=5.4 ; \mathrm{MnCl}_{2} .4 \mathrm{H}_{2} \mathrm{O}=4.8 ;$ $\mathrm{CuCl}_{2} \cdot 2 \mathrm{H}_{2} \mathrm{O}=3.6 ; \mathrm{Na}_{2} \mathrm{MoO}_{4} \cdot 2 \mathrm{H}_{2} \mathrm{O}=3.1$ and $\mathrm{ZnCl}_{2}=0.3$. 


\section{Enzyme Production}

The experiments were carried out in an aerated and stirred bioreactor with a volume of 5 liters (BIOFLO IIC, New Brunswick Scientific), operated in batch and fed-batch modes during 48 hours. The temperature was maintained at $30.0{ }^{\circ} \mathrm{C}$, the airflow rate at 2.0 SLPM (standard liter per minute) and dissolved oxygen at $20 \%$ of the saturation through automatic control of the stirring speed during the cultivation process.

Samples were taken from the bioreactor periodically (two-hour or four-hour intervals) and centrifuged at $14,000 \mathrm{~g}$ for 20 minutes at $4^{\circ} \mathrm{C}$. The sedimented material was collected and dried to determine cell concentration, and the supernatant was used to carry out further analyses (amino acids and enzyme concentrations). The composition of the production medium is shown in Table 2.

Table 2: Composition of the production medium.

\begin{tabular}{|l|c|}
\hline \multicolumn{1}{|c|}{ Nutrients } & Concentration $\mathbf{( g / L )}$ \\
\hline Solution of amino acids & 10.0 \\
Cheese whey & 19.6 \\
Phenyl acetic acid (inductor) & 2.7 \\
Solution of salts & 0.9 \\
\hline
\end{tabular}

\section{Analytical Methods}

\section{a) Enzyme Activity}

Enzyme activity was determined by hydrolysis of $0.2 \mathrm{M}$ penicillin $\mathrm{G}$ at $\mathrm{pH} 8.0$ (10 $\mathrm{mM}$ phosphate buffer) and $37{ }^{\circ} \mathrm{C}$. The 6-APA produced was measured spectrophotometrically at $415 \mathrm{~nm}$ after reaction with p-dimetilaminebenzaldehyde (PDAB), following Balasingham et al. (1972). An international unit (IU) is the amount of enzyme that catalyzes the formation of $1 \mu \mathrm{mol}$ of 6 -APA from penicillin $\mathrm{G}$ in $1 \mathrm{~min}$ under these conditions.

\section{b) Amino Acids Concentration}

Amino acids were quantified using an LC gradient system (Shimadzu) with two high-pressure piston pumps. A Shim-Pack Amino NA column (Shimadzu) was employed at $60^{\circ} \mathrm{C}$ in a Model CTO-10A column oven. Sodium citrate $(0.2 \mathrm{~N}, \mathrm{pH} 3.2)$ in $7 \%$ ethanol, sodium citrate $(0.6 \mathrm{~N}, \mathrm{pH} 10)$ and sodium hydroxide $(0.2 \mathrm{~N})$ were the eluents. A pump (Model LC-10AD) was used for post-column addition of the derivatization solution, consisting of o-phthalaldehyde and an alkali buffer solution. Fluorescence detection (excitation at $360 \mathrm{~nm}$ and emission at $450 \mathrm{~nm}$ ) was obtained with an RF-10A detector.

\section{c) Phenyl Acetic Acid Concentration}

Phenyl acetic acid was measured by high performance liquid chromatography (HPLC): column C18 (Waters Nova-Pak) 60 4 mm diameter, $3.9 \times 150 \mathrm{~mm}$. The eluent consisted of $25 \%$ acetonitrile, $10 \mathrm{mM}$ of $\mathrm{H}_{3} \mathrm{PO}_{4}$ and $5 \mathrm{mM}$ of $\mathrm{K}_{2} \mathrm{H}_{2} \mathrm{PO}_{4}$ $\left(\mathrm{pH} 4.6\right.$ and $25^{\circ} \mathrm{C}$ ). The wavelength was $225 \mathrm{~nm}$ and the flow rate $1 \mathrm{ml} / \mathrm{min}$.

\section{RESULTS AND DISCUSSION}

After intense study by experiments in shaking flasks to determine a medium composition that would maximize enzyme production, the medium with the free amino acids described in Table 1 was used at $10 \mathrm{~g} / \mathrm{L}$. In the first experiments using casein hydrolyzed by alcalase, the highest production of PGA achieved was $90 \mathrm{IU} / \mathrm{L}$. The enzymatic hydrolysis of casein releases, besides free amino acids, peptides of wide-ranging molecular weights. Thus, one possible reason for this low value of enzyme activity could be the need of the microorganism to activate mechanisms to hydrolyze these peptides. Therefore, a solution of amino acids reproducing the composition of casein was employed. Several experiments were carried out in shaking flasks with the new medium and enzyme activities rose to $200 \mathrm{UI} / \mathrm{L}$.

After these results in shaking flasks, experiments were run in the bioreactor. The first experiment using the new medium containing free amino acids (aa) was denominated standard batch experiment. The experimental conditions were the following: a temperature of $30.0{ }^{\circ} \mathrm{C}$, dissolved oxygen at $20 \%$ saturation (by automatic control of stirrer speed) during the whole fermentation process, addition of inductor phenyl acetic acid (PAA) at the beginning 
of cultivation, a working volume of 4.5L (4.0L of medium and 0.45 of inoculum) and a duration of 41 h. Figure 1 shows graphs of cell and PAA concentrations, enzyme activity and total concentration of aa. It can be observed in Figure 1 that the cell concentrations did not exceed $4.6 \mathrm{~g} / \mathrm{L}$ and that enzyme activity reached a maximum of 180 IU/L, confirming the results obtained in the shaking flasks. PAA was depleted in the initial 15 hours of cultivation, indicating its use as a carbon source for the microorganism. The depletion of PAA and amino acids caused stagnation of the cell concentration and enzyme activity. Analysis of the consumption of each amino acid (Figure 2) shows that some were quickly consumed (Figure 2a), while others had a slower rate of assimilation (Figure 2b). The preferential amino acids were consumed in less than 10 hours and the others mostly after that period.

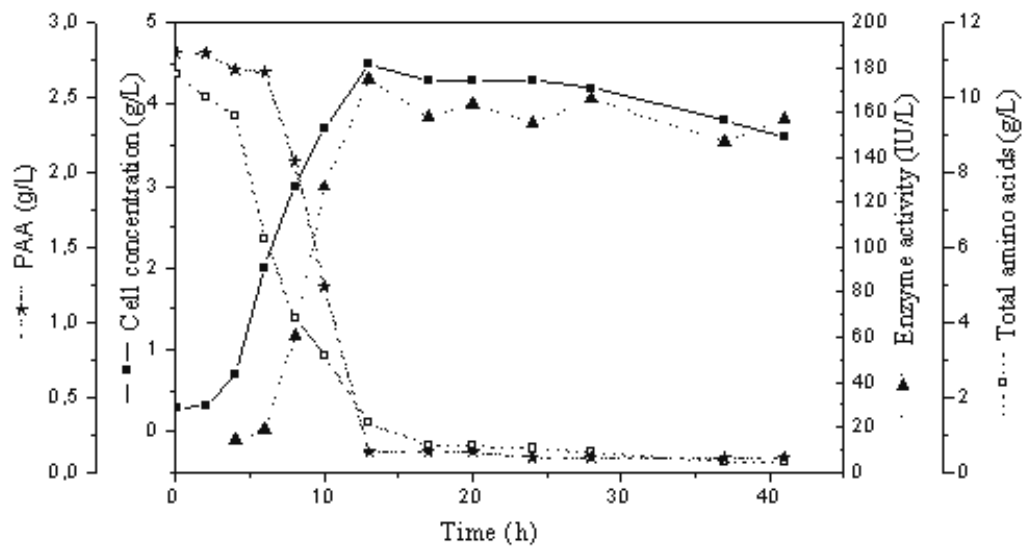

Figure 1: Cell concentration, enzyme activity, PAA concentration and total amino acid concentration during the batch cultivation.

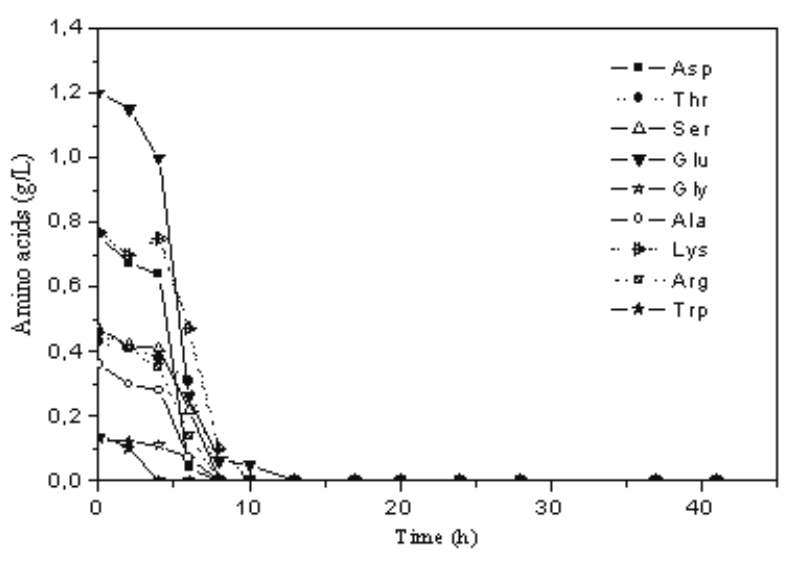

(a)

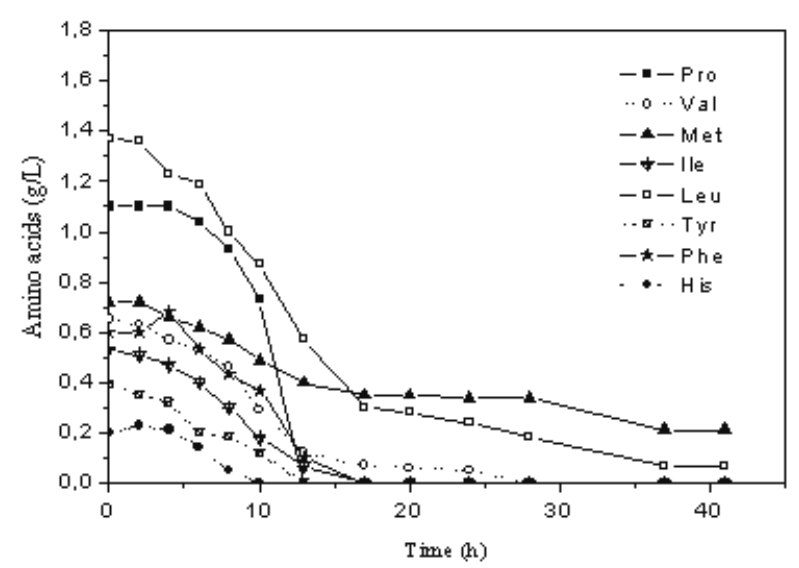

(b)

Figure 2: Amino acids concentrations: (a) preferential consumption; (b) slow consumption.

The stagnation of cell growth and of enzyme production, coinciding with the depletion of PAA and amino acids, indicated the possibility of expanding the exponential growth phase. Therefore, a fed-batch culture (Experiment BA1) was carried out. The supplementary medium was the same solution of amino acids. This was an attempt to extend the exponential growth phase, consequently increasing the amounts of PGA produced. The results in Figure 1 clearly indicate that the production of the enzyme was growthassociated, maybe with a two-hour delay. Other experimental conditions of experiment BA1 were the same as those of the previous one, except for cultivation time (46 hours). The total volume of supplemental medium added at a flow rate of 1.76 $\mathrm{mL} / \mathrm{min}$ was $1 \mathrm{~L}$. This solution was fed after 8 hours of cultivation because at that point the preferred amino acids were almost depleted (Figure 2-a). 


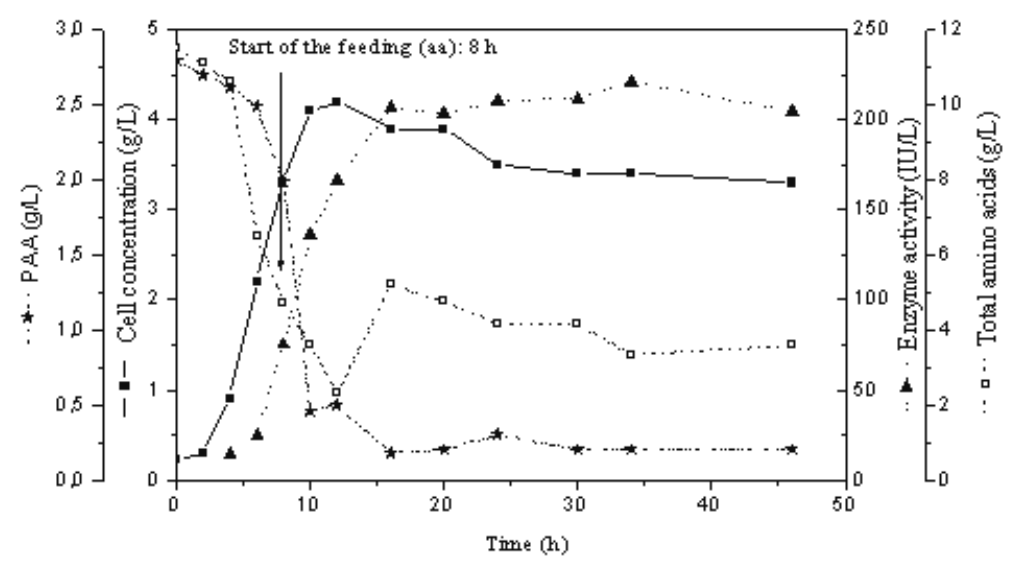

Figure 3: Cell concentration, enzyme activity, PAA concentration and total amino acids concentration during the fed-batch cultivation (Experiment BA1).

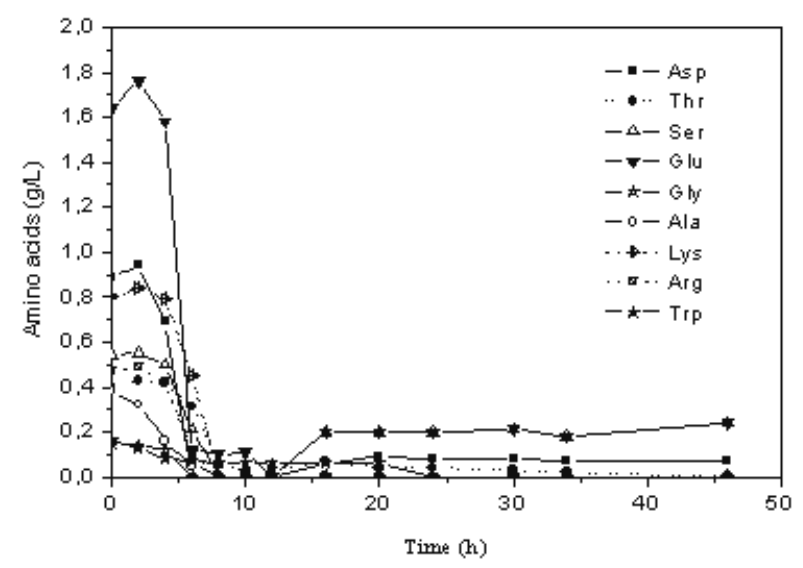

(a)

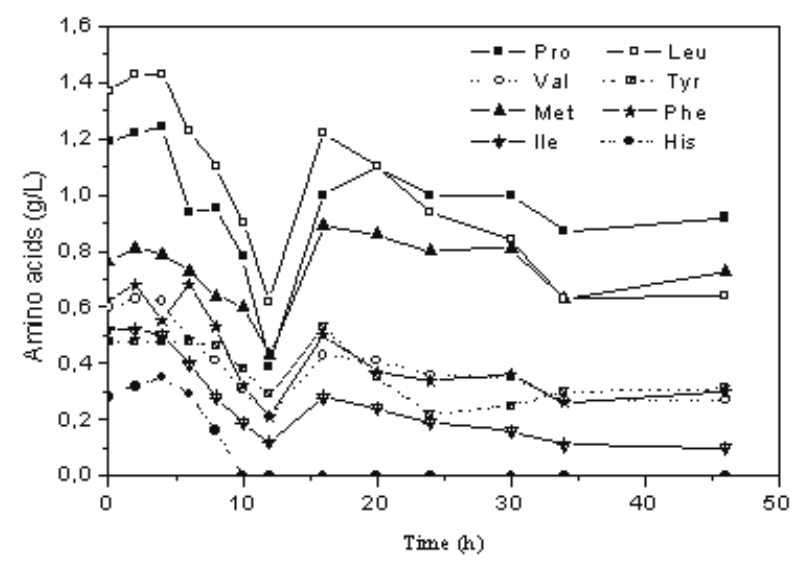

(b)

Figure 4: Amino acids concentration: (a) preferential consumption; (b) slow consumption.

Figure 3 shows a small improvement upon the experiment in batch culture, with slightly higher values of enzyme activity (200 IU/L). The exponential phase, however, could not be extended beyond the same $12 \mathrm{~h}$ time span (approx.) that was observed in the batch run. It is interesting to observe that, in the fed-batch, some aa were depleted (their consumption continued even during the stationary phase), while others accumulated (see Figure 4 for the details). These data surely reflect changes in the metabolic pathways when the exponential growth is completed.

A second fed-batch experiment was conducted (Experiment BA2) with separate feeds of amino acids and cheese whey, which provides essential micronutrients for microorganism growth: there is no germination of the spores without whey. The experimental conditions were the same as those in BA1, except that the feeding of amino acids began after $5 \mathrm{~h}$ instead of $8 \mathrm{~h}$ of cultivation, as in the one with cheese whey. Feeding amino acids after 5 hours was an idea suggested by the results of experiment BA2 (see Figure 4-a) where some amino acids were depleted in less than 8 hours.

An increase in biomass concentration upon the previous experiment was observed, most probably caused by the feed of cheese whey. The highest value for enzyme activity of all the experiments on the PGA production was obtained in the bioreactor. Generally speaking, a better performance was observed for the fed-batch experiments. 


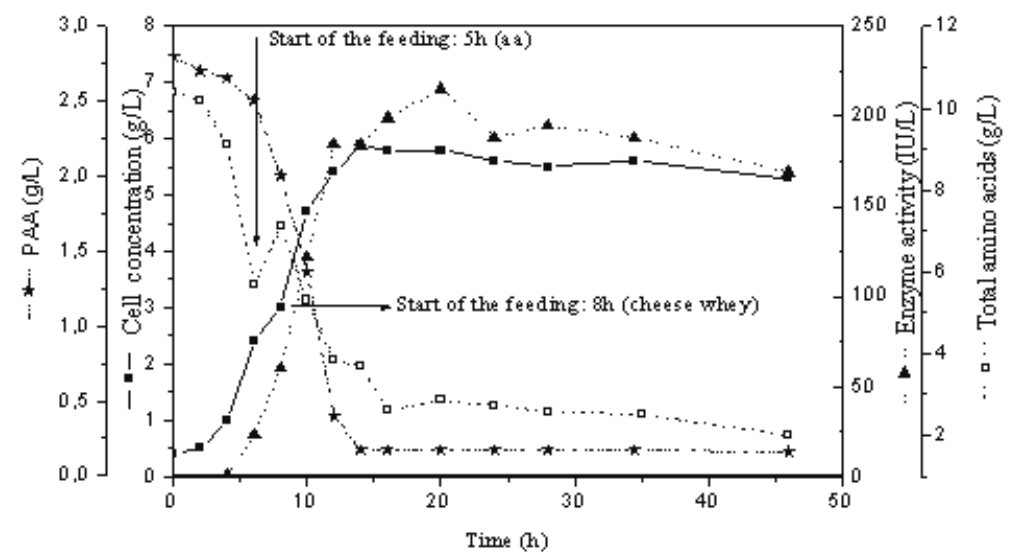

Figure 5: Cell concentration, enzyme activity, PAA concentration and total amino acids concentration during the fed-batch cultivation (Experiment BA2).

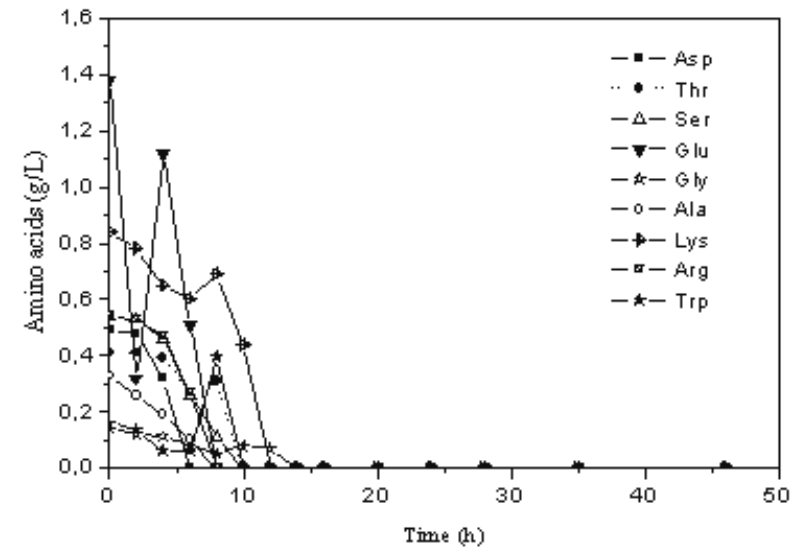

(a)

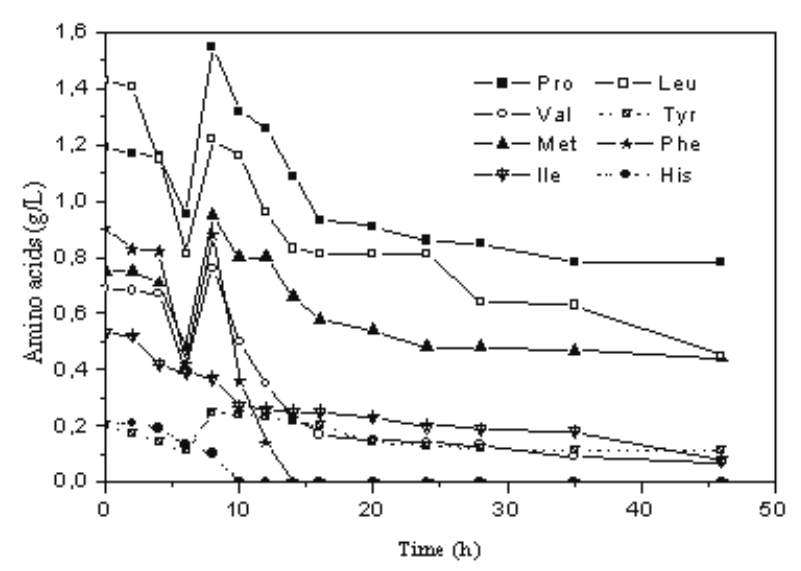

(b)

Figure 6: Amino acids concentration: (a) preferential consumption; (b) slow consumption.

\section{CONCLUSIONS}

The substitution of hydrolyzed casein by a solution of free amino acids during the cultivation of Bacillus megaterium resulted in higher rates of biomass growth and of PGA production. Fed-batch cultivations showed a small improvement upon batch operation with higher values of enzyme activity and of cell concentration. Nevertheless, the exponential growth phase could not be extended appreciably with the strategies tested here. Enzyme production was shown to be associated with cell growth after a delay of approximately 2 hour.

The wild B. megaterium strain ATCC 14945 grew satisfactorily in a medium with free amino acids. A set of these amino acids, Ala, Arg, Asp, Gly, Lys, Ser, Thr and Trp was preferentially consumed by the microorganism. On the other hand, the rates of consumption of His, Ile, Leu, Met, Phe, Pro, Tyr and Val were lower. Further single omission assays will be carried out to verify whether some of these amino acids are essential.

\section{ACKNOWLEDGEMENTS}

The authors thank FAPESP and CNPq for their financial support and Ajinomoto Interamericana Ind. e Com. (Brazil) for the generous gift of the amino acids used throughout the experiments. 


\section{REFERENCES}

Acevedo, F. and Cooney, C.L., Penicillin Amidase Production by Bacillus megaterium. Biotechnology and Bioengineering, 15, pp. 493503 (1973).

Balasingham, K., Warburton, D. Dunnil, P. and Lilly, D., The Isolation and Kinetics of Penicillin Amidase from Escherichia Coli. Biochimica ET Biophysica Acta, pp. 250-256 (1972).

Gentina, J.C., Acevedo, F. and Villagra, M.P., Short Communication: Effect of Complex Nitrogen Sources on the Production of Penicillin Acylase by Bacillus megaterium. World Journal of Microbiology and Biotechnology, 13, pp. 127128 (1997).

Illanes, A., Acevedo, F., Gentina, J.C., Reyes, I., Torres, R., Cartagena, O. and Ruiz, M. A., Production of Penicillin Acylase from Bacillus megaterium in Complex and Defined Media. Process Biochemistry, 29, pp. 263-270 (1994).

Illanes, A., Biotecnologia de Enzimas, Ediciones Universitarias de Valparaíso de la Universidad Católica de Valparaíso, Chile (1994).

Modak, J.M. and Lim, H.C., Optimal Mode of Operation of Bioreactor for Fermentation
Process. Chemical Engineering Science, 47, no. 15-16, pp. 3869-3884 (1992).

Ospina, S.S., Characterization and Use of a Penicillin Acylase Biocatalyst. Journal of Chemical Technology and Biotechnology, 53, pp. 205-214 (1992).

Pinotti, L.M., Silva, A.S., Silva, R.G and Giordano, R.L.C., Study of Different Media for Production of Penicillin G Acylase from Bacillus megaterium ATCC 14945. Applied Biochemistry and Biotechnology, 84-86, pp. 655-663 (2000).

Schmidell, W., Lima, U.A., Aquarone, E. and Borzani, W., Biotecnologia Industrial: Engenharia Bioquímica, Editora Edgard Blucher LTDA, 2, Brazil (2001).

Souza, V.R., Pinotti, L.M., Inocêncio, G.E.M. and Giordano, R.L.C., Influence of Amino Acids Composition in the Production of Penicillin G Acylase by Bacillus megaterium ATCC 14945. 7th SHEB, Maringá, PR (2002).

Whitaker, A., Fed-batch Culture. Process Biochemistry, 15, pp. 10-15 (1980).

Yamane, T. and Shimizu, S., Fed-batch Techniques in Microbial Processes. Advances in Biochemical Engineering/Biotechnology, 30, pp. 148-194 (1984). 